\title{
Effect of terrorism activities on capital flight in the Middle East
}

\author{
Anahita Seifi ${ }^{1 *}$,Samira Motaghi $^{2}$,Salah Ebrahim ${ }^{3}$, Mojtaba Soltani Ahmadi ${ }^{2}$ \\ ${ }^{1}$ Allameh Tabataba'i University, Dehkade-ye Olympik, West Hemmat Highway, Tehran, 1489684511, \\ Iran \\ ${ }^{2}$ Payame Noor University,Minn City,Artesh Blvd,Thran,193954697, Iran \\ ${ }^{3}$ Chamran University, Golestan Blvd,Ahvaz,6135783151,Iran,
}

\begin{abstract}
Behavioral economics has proven that negative emotions can influence investors' decisions. One of the factors that have a negative impact on investors' sentiment is terrorism as the new face of violence with economic consequences. The link between terrorism and capital outflow is a theoretical framework that explains how violence affects capital flight of a country. With this in mind, the purpose of this study is to investigate the effect of terrorist activities on capital flight in the Middle East countries during the period 2000-2016 using the Spatial Econometric Panel Data Approach. The results of this study show that terrorism and its spatial effects have a significant and positive impact on capital flight in the Middle East countries. Also, gross domestic production (GDP) and trade openness have negative effects on capital outflow. This study has important implications for policymakers in countries facing terrorist activity and investors' trust building.
\end{abstract}

\section{Introduction}

Increasingly negative events around the world, including natural disasters, artificial and military disasters, have led researchers to focus their attention on the impact of such an event on the economy and the capital market $[18,37,24]$. Behavioral economics studies believe that negative events influence investment decisions. These emotional decisions of the investor can affect asset prices, stock markets, and capital movements [12,33]. The findings of behavioral economics have shown that people's temperament influences their decisions even when the cause of this mood is not related to the decision made. Since people's moods influence their decisions, buying and selling stocks in global markets is no exception, and investors' moods affect the decision to move capital in the market. People's trading behavior is strongly influenced by emotions such as anger, confusion, and distress [27].

The distribution of global capital depends on social, financial, and political factors. Multinationals consider the political stability of the host country when investing overseas. The social, economic and political conditions of the host country largely determine the amount of foreign capital. Hence, the host countries make great efforts to ensure political stability and attraction for multinational companies and foreign investors. Over the past

*Corresponding author: a.seifi@atu.ac.ir 
decade, political instability, insecurity, conflict, and terrorism have increased significantly $[35,14,12,17]$. The concept of security has evolved over time and attitudes toward security have changed. Security used to be in the simple sense of the absence of military confrontation. But today, the concept of security has gradually evolved and departed from its traditional sense of focusing on military dimensions, inter-state conflicts and border threats. In the modern sense, security encompasses many aspects such as economic, social, cultural, political, and environmental aspects [13]. Terrorist activities are an important variable in security studies and it is detrimental to all kinds of security [17]. In addition, due to the dramatic increase in terrorist attacks over the last two decades, host economies have taken extensive steps to improve the political, social, and economic situation by reducing external conflicts and terrorist attacks. The Global Terrorism Database (GTD) identifies terrorism as a threat or actual use of illegal or violent force by a non-governmental person or group to achieve a political, economic, religious, or social goal through fear. This is because these activities are designed to create psychological effects and their effects go beyond the victims of terrorist incidents [12]. The impact of terrorism on consumer behavior decisions and investment decisions is crucial. Terrorist events can be considered as a disruption in conflict sites and new destinations because investors prefer peaceful social environments based on their preferences as well as for peace [13]

In recent years, with the increasing number of terrorist incidents around the world, the impact of terrorist activities on macroeconomic variables has become an attractive topic for researchers $[2,14,4]$. It is argued that stock prices reflect investors' hopes and fears about the future. Given the high liquidity of equity markets, when information on terrorist attacks as well as other risky events is anticipated, investors can look for more sustainable financial instruments in the market [9]. Terrorism also has negative effects on factors of production (such as labor and capital). In addition, terrorism causes instability and uncertainty in the economy and destabilizes investment decisions, negatively affecting capital inflows and positively affecting capital outflows [33].

According to the GTD (2018), the highest number of casualties in the world, and especially since 2001, has been concentrated in the Middle East. Given that problems such as high unemployment rates, currency constraints, single-product economics, low levels of per capita income, and low rates of economic growth are clearly evident in the Middle East, these countries need to attract foreign investment to overcome such problems. Given the currency constraints in these countries, attracting foreign investment can play a significant role in this regard. Identifying the effects of capital flight terrorist events in these countries can help policymakers improve or maintain the status quo. Therefore, the purpose of this article is to investigate the effect of terrorist events on capital flight in a number of Middle East countriest during the period 2000-2016 using the Spatial Econometric Panel Data Approach.

The rest of the article first reviews the distribution of terrorist incidents throughout the world. Theoretical literature and empirical studies on terrorism and capital flight will then be reviewed. The next section presents the research model. After that, the model estimation and interpretation of the results are presented. The final section also concludes with research suggestions.

\section{A review of post-World War II modern terrorism}

The use of terrorism to pursue a political goal has increased in recent years. Modern terrorism began largely after World War II with the rise of nationalist movements in the old empires of European powers. The 9/11 attacks were a turning point in the history of the world and the

\footnotetext{
${ }^{\dagger}$ Including Iran, Kuwait, Qatar, Iraq, UAE, Egypt, Lebanon, Saudi Arabia and Jordan.
} 
beginning of the war on terrorism. It is estimated that 3,000 people have been killed in the attacks and it is the deadliest terrorist incident in human history. The subsequent war on terror led to the invasion of Afghanistan in 2001 and Iraq in 2003. Table (1) summarizes the concentration of terrorist attacks before and after $9 / 11$ in different regions.

Table 1. Terrorist activities in the world before and after 9/11 (10 countries with the highest number of terrorist attacks)

\begin{tabular}{|l|c|l|c|}
\hline From 1970 to September 11,2001 & \multicolumn{3}{|l|}{ From September 11,2001 to 2016 } \\
\hline Country & $\begin{array}{l}\text { from total } \\
\text { terrorist activities }\end{array}$ & Country & $\begin{array}{l}\text { from total } \\
\text { terrorist activities }\end{array}$ \\
\hline Columbia & 8.88 & Iraq & 25.77 \\
\hline Peru & 8.35 & India & 9.48 \\
\hline El Salvador & 7.38 & Afghanistan & 9.03 \\
\hline Northern Ireland & 5.13 & Pakistan & 7.63 \\
\hline India & 4.61 & Syria & 5.84 \\
\hline Spain & 4.14 & Philippines & 3.85 \\
\hline Turkey & 3.49 & Russia & 3.65 \\
\hline Chile & 3.15 & Columbia & 3.22 \\
\hline Sri Lanka & 3.03 & Thailand & 2.89 \\
\hline Philippines & 2.96 & Nepal & 2.55 \\
\hline
\end{tabular}

Source: GDP (2018)

Table (1) shows that terrorist activity prior to 9/11 was concentrated in Latin America, part of Europe and East Asia. After 9/11, the focus was mainly on the Middle East. The focus of terrorist activities during the years 2010-2017 was mainly on Syria, Iraq, and Afghanistan by extremist groups such as the Taliban, al-Qaeda and ISIS. The trend of the number of terrorist activities in the world from 1970 to 2016 has been shown in diagram (1).

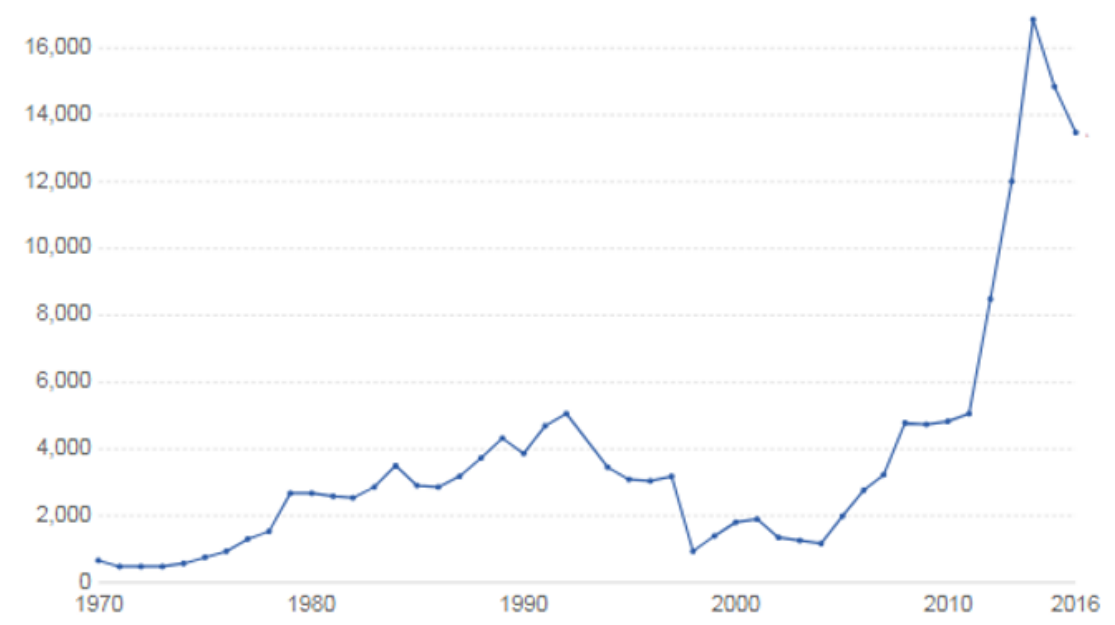

Fig. 1. Number of terrorist activities (source: GTD, 2018)

According to diagram (1), a large jump in the number of terrorist activities occurred worldwide between 2010 and 2015, mainly due to the increase in terrorist operations in Iraq and Syria. As the terrorist attacks in the Middle East have increased in recent years, the number of those killed has also increased. As with the number of terrorist activities, the number of those killed has increased, with the highest number of casualties being in the Middle East and North Africa. Figure (2) also shows the distribution of terrorist activities in the world. 


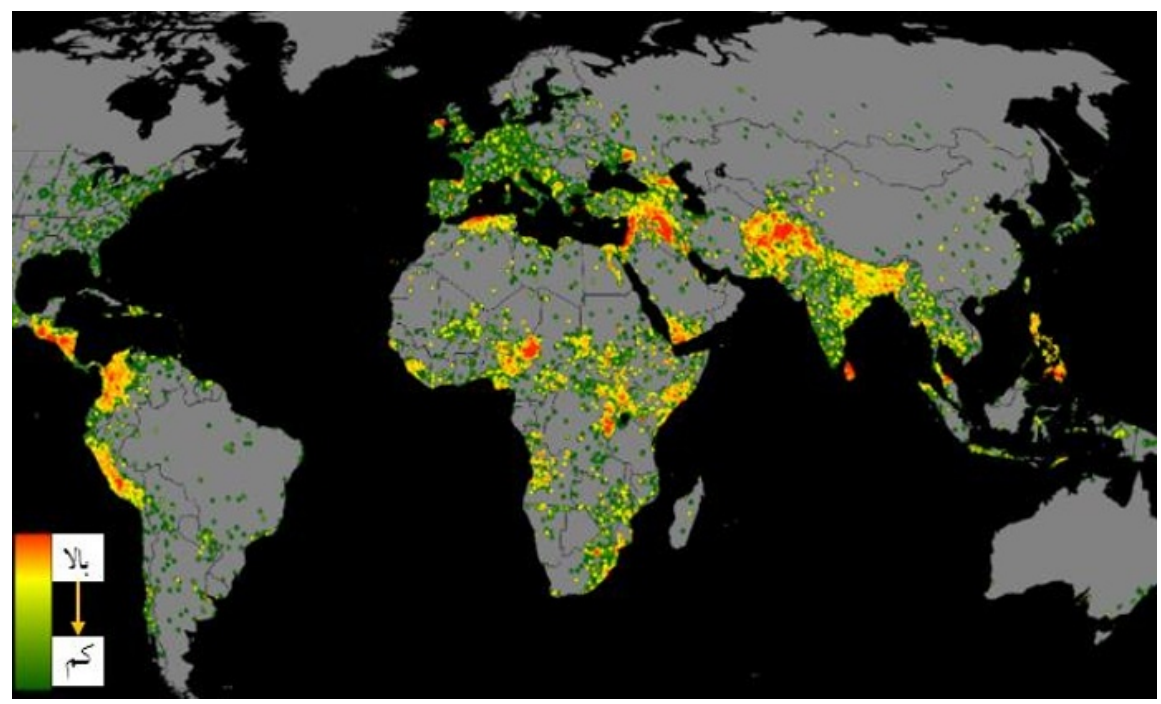

Fig. 2. Distribution of the number of terrorist incidents in the world from 1970 to 2016 (Source: GTD, 2018)

According to Figure (1), the major focus of terrorist activity over the past 46 years has been concentrated in the Middle East, Afghanistan, Pakistan, South America and Central Africa. The point in the data structure is the widespread increase in terrorist attacks in the Middle East following the 9/11 events in 2001 and the US invasion of Afghanistan and Iraq. In other words, terrorist activities before 2001 have been concentrated in areas of the United States, Eastern Europe, and a few countries in the Middle East, but since the US invasion of Afghanistan and Iraq, the major focus of terrorist activity has been concentrated in the Middle East.

\section{Literature review}

Terrorism is defined, in the modern sense, by the French word "terror", which means extreme fear and anxiety that have special effects on people and usually means unconscious reaction. Global terrorism has become a reality in today's society. Terrorism can be divided into two main categories: domestic terrorism and transnational terrorism. Domestic terrorism has grown and practiced within a country and its casualties are limited to the same country. This is in contrast to the transnational terrorism with perpetrators, supporters, victims, and audiences who are sometimes from two or more countries [7]. The effects of terrorism are different from other forms of violence such as war, civil strife and instability. Terrorism and other forms of violence are similar in terms of its effects, which are mainly the loss of life and property. However, there is also a distinction between goals and their effects. In the field of terrorism, people are mostly targeted [18] and seek to increase anxiety within their target community in order to impose their desires or to create psychological stress in the community [15]. On the other hand, the targets of other forms of violence are often military and government forces [12,8]. Enders et al. (2006) define terrorism as using or threatening to use unofficial violence to achieve political ends through intimidation or fear directed at a large audience. In other words, there is a political purpose that terrorist acts are designed to achieve it. The main short-term goal of terrorist activities is economic instability. Terrorist attacks (such as bombings and assassinations) are meant to achieve this short-term goal $[14,13]$. Long-term political goals (such as redistribution of power and wealth) are likely through such terrorist attacks. Taken together, these factors adversely affect investment of other countries 
in the target country by creating insecurity.

The effect of terrorism on capital flight is a subject that has not yet been adequately empirically analyzed, and most studies in this field are theoretical. Collier (1999) states that civil wars as a measure of violence will increase the outflow of capital from the country due to its nature. The military conflict will increase the uncertainty of the future return on assets in the country and capital will seek alternative markets. One of the most important factors in deciding whether to invest in a region or country is the absence of terrorist activities in that region or country [1]. The increased number of terrorist incidents in a particular region not only reduces the willingness to invest in that area, but also provides the opportunity for capital outflows. Multinationals largely avoid investing in these areas because of the insecurity and instability caused by terrorist attacks [31]. Terrorist incidents increase the risk of capital retention and pessimism about the future return on capital, thus stimulating capitalists to withdraw their capital from a disputed area [11]. Terrorism can also be a source of direct costs to countries. Terrorists' goals for these activities have long-term negative effects on society. The economic impact of a terrorist act can exist for many years after a terrorist attack [23]. Abadie and Gandeazab (2003) research on the theoretical insight into terrorist activities has shown that terrorism increases global insecurity and has a negative impact on the distribution and transfer of capital and investment in different countries. Tavares (2004) showed that the increase in international terrorist activity also affects the economic development of countries at risk of terrorism. He showed that intense terrorist activity has led to tax cuts and total government revenue in some countries and has had negative effects on public services and government investment [6]. Taken together, these factors illustrate the negative impact of terrorism on economic growth.

Alomar and El-Sakka (2011) examined the effects of terrorism on foreign direct investment flows in 136 developing countries using the panel data approach over the period 1998-2008. The results of this study showed that terrorism had a significant negative impact on the flow of foreign direct investment. In an empirical study on Pakistan, Shahbaz et al. (2013) have shown the negative effects of terrorism on foreign capital in Pakistan.

Bandyopadhyay et al. (2014) used Panel Data approach and examined the effect of terrorism on capital outflow in 72 developing countries during the 1990-2010 period. The results of this study showed that terrorism accelerates the outflow of capital through increased investment risk, anxiety and increased capital maintenance costs.

Efobi and Asongu (2016) carried out a study entitled "Terrorism and Capital Flight in Africa" and examined the effects of terrorism on capital flight in African countries using the panel data approach over the period 1987-2008. The results of this study showed that terrorism had a positive effect on capital flight in the countries studied.

In a similar study, Alam et al. (2017) also examined the effect of terrorism on foreign direct investment in Pakistan over the period 2000-2015 using the OLS method. The results of this study showed that terrorism had a significant negative effect on attracting foreign investment in Pakistan.

In Iran, Davoodi and Shahmoradi (2007) carried out a study entitled "Recognizing the Factors Affecting Foreign Direct Investment Attraction in Iranian Economy and 46 Countries of the World" and investigated the effective factors of attracting foreign investment within a panel model. The purpose of this study was to investigate the factors affecting foreign direct investment attraction in 47 developing countries during the period 1999-2004. The results showed that attention to legal infrastructure, encouragement and strengthening of private sector investment, attention to efficiency and productivity of investments in infrastructure and research and development, attention to efficiency, productivity and skill level of labor force and measures to increase the political stability of the country may be able to attract more foreign direct investment in Iran and the countries under study.

Moshiri and Kianpour (2012) also studied the factors affecting the attraction of foreign 
direct investment using panel data in 209 countries during the period 1980-2007. The analysis is done in the context of a fixed effect model to distinguish the specific differences of each country. In addition, in the estimated model, specific regional effects are also controlled. The results of the model estimation showed that the effect of degree of openness, rate of return on capital, infrastructure, human capital and volume of investment in the previous period had a positive and significant effect on attracting foreign direct investment. However, the variables of government spending, corruption and inflation have not had a significant impact on foreign direct investment.

Soleimani et al. (2014) examined the effect of terrorism shocks on the attraction of foreign direct investment in MENA countries using the VAR panel method over the period 19702012. The results of model estimation and investigating the interrelationships of research variables in terms of instantaneous reaction functions and variance analysis showed that during the study period, terrorism shocks have a negative effect on attracting foreign direct investment. Conversely, shocks due to GDP and degree of trade openness have had a positive effect on attracting foreign direct investment.

\section{Model and method of data analysis}

Spatial econometrics is a subset of econometrics that deals with the interactions between geographical units. Units can be zip codes, cities, municipalities, districts, provinces, governments, jurisdictions, countries, etc. depending on the nature of the study. Spatial econometric models can also be used to explain the behavior of economic agents and other geographical units, such as individuals, companies, or governments, if they are linked through a network. This type of research, although developed, is less common. The literature on time series focuses on the relationship between observations over time and uses the $t-1$ sign to indicate the lag of time series variables. Spatial econometric texts are interested in the interdependence between observations across space and use the spatial weight matrix $\mathrm{W}$ to describe the order of geographical units in the sample. Spatial econometrics is not a simple expansion of econometrics into two dimensions. One obvious difference is that two geographical units can interact with each other, while two observations cannot affect each other over time [10]. According to Getis (2007), another complex factor is the wide variety of units of measurement that can be selected for modeling spatial dependence (neighborhood, distance, relationships, etc.) that are compared with the time dependency scale. In the last decade, spatial econometric literature has shown an increasing tendency to profile and estimate econometric relationships based on spatial panel. Spatial panel data typically refers to data that includes observations of time series in a number of geographical units. This interest can be explained by the fact that panel data suggests researchers extend the possibility of modeling to explain causal relationships, which is compared to the position of a crosssectional time equation. At first, spatial econometrics focused on the long run. Panel data are generally more informative and have more variability. In these data, there is often less linearity between variables. Using panel data leads to greater freedom of access and increased efficiency of estimation. Panel data can be used to characterize more complex behavioral hypotheses, including effects that cannot be demonstrated using pure cross-sectional data [29]. Geo-spatial econometric uses one of two criteria of relevance as follows. One is the proximity binary measure, where the units are closer than a specified threshold value and the other is a continuous criterion that measures the distance between two units. This measure can be based on two reference points, such as the capital cities of the two countries or the minimum distance between the two closest points to the external borders of the two countries. However, the word 'neighborliness' usually means geographical proximity. This technique claims to have better capability and applicability than conventional econometrics in spatial and regional studies. This method allows determining the distance of each point in space 
from another point (5).

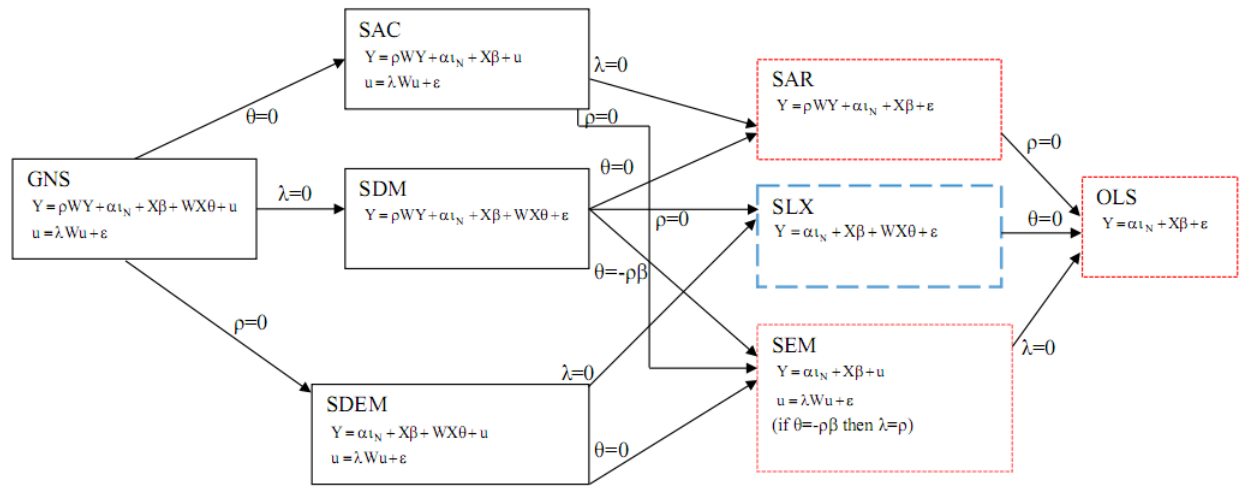

Fig. 3. Different stipulations of spatial econometric(SDM: Spatial Durbin Model; SDEM: Spatial Durbin Error Model; SAR: Spatial Autoregressive Model; SEM: Spatial Error Model; OLS: Ordinary Least Squares Model; SLX: Spatial Lag of X Model; SAC: Spatial Autoregressive Combined; GNS: General Nesting Spatial Model)

According to the method described above, the model to be studied in this study is as follows. Its basic model is adapted from the study of Efobi and Asongu (2016).

$$
\mathrm{CO}=\mathrm{A}_{0}+\mathrm{A}_{1} \text { terit }+\mathrm{A}_{2} \text { gdpit }+\mathrm{A}_{3} \text { tropenit }+\mathrm{A}_{4} \text { wterit }+\mathrm{A}_{5} \text { wgdpit }+\mathrm{A}_{6} \text { lnwtopennit }+\mathrm{Uit}
$$

Where, CO is capital outflow (capital flight), TER is the number of terrorist incidents, GDP is gross domestic production per capita, OPEN is also trade openness, $\mathrm{W}$ is also the spatial effects of the terrorism variables, GDP per capita and trade openness. The data for this study were collected from the World Bank website and GTD. Data were analyzed using Eviews 9 and Stata 14 software.

\section{Model estimation. Reliability test results}

The application of traditional econometric methods is based on the assumption that the variables are static. Therefore, in order to avoid the occurrence of false regression when estimating the model, it is necessary to first test the variables' stability. To test the reliability of the variables, the Linn and Levin test (LL) is used, which is more applicable in the stationary investigation of variables in the panel data. Evaluation of the tests is done by means of Eviews 9 software and significance test by Prob at 5\% level. Since the calculated probability is less than $5 \%$, the hypothesis of a unit root for that variable is rejected. The results of the static test of variables are shown in Table (2).

Table 2. Results of static test of variables by Lin and Levine method

\begin{tabular}{|l|l|l|l|}
\hline Variable & Test statistics & Probability & Static/non-static \\
\hline CO & -3.78 & 0.00 & Static \\
\hline GDP & -2.98 & 0.00 & Static \\
\hline TOPENN & -4.76 & 0.00 & Static \\
\hline TER & -3.43 & 0.00 & Static \\
\hline
\end{tabular}

Based on the test results, the research variables are static. Before estimating the spatial model, the presence or absence of spatial effects must first be examined. These tests include the Moran test and the Lagrange Multiplier Test (LM). The test results are presented in Table (3).

Table 3. Detection test results for the use of spatial effects 


\begin{tabular}{|l|l|l|}
\hline Test & Test statistics & Probability \\
\hline Moran & 6.02 & 0.00 \\
\hline LM & 9.11 & 0.00 \\
\hline
\end{tabular}

The results show that the null hypothesis that no spatial effects exist for both the Moran test and the Lagrange coefficient is rejected. In other words, there are spatial effects between the research variables.

Following is a spatial Hausman test to investigate the temporal and spatial fixed effects. The results indicate confirmation of fixed effects versus random effects.

Table 4. Spatial Hausman test

\begin{tabular}{|l|l|l|l|}
\hline Null hypothesis & Statistics & P-value & Result \\
\hline $\begin{array}{l}\text { Fixed effects of space are not } \\
\text { jointly significant. }\end{array}$ & 26.02 & 0.0000 & Rejected \\
\hline $\begin{array}{l}\text { Fixed effects of space and time } \\
\text { are not jointly significant. }\end{array}$ & 23.14 & 0.0000 & Rejected \\
\hline
\end{tabular}

Given that both effects are jointly significant, the spatial model used in this study will be bilateral fixed effects. The model estimation results are presented in Table (5).

Table 5. Model estimation results

\begin{tabular}{|l|l|l|l|l|}
\hline Method & \multicolumn{2}{|l|}{ Spatial fixed effects } & \multicolumn{2}{l|}{ Spatial-temporal fixed effects } \\
\hline $\begin{array}{l}\text { Explanatory } \\
\text { variable }\end{array}$ & Coefficient & T-statistics & Coefficient & T-statistics \\
\hline $\mathrm{C}$ & 0.076 & 4.11 & 0.0463 & 1.89 \\
\hline GDP & -0.175 & -2.34 & -0.140 & -2.11 \\
\hline OPEN & -0.032 & -1.66 & -0.0054 & -1.67 \\
\hline TER & 0.052 & 2.58 & 0.032 & 2.43 \\
\hline WGDP & -0.0221 & -2.21 & -0.0758 & -1.78 \\
\hline WOPEN & -0.00244 & -2.11 & -0.0464 & -2.43 \\
\hline WTER & 0.0841 & 1.78 & 0.0364 & 2.24 \\
\hline $\begin{array}{l}\text { Statistical } \\
\text { tests }\end{array}$ & $\begin{array}{l}\text { F-statistics }=0.00 \\
\text { R2 }=0.71\end{array}$ & $\begin{array}{l}\text { F-statistics }=0.00 \\
\text { R2 }=0.77\end{array}$ \\
\hline
\end{tabular}

The results of Table 5 for the fixed effects model show that the estimation model is in good condition in terms of statistical indices. The F-statistic indicates the significance of the whole regression. In other words, the hypothesis that the coefficients of the independent variables of the model can be zero is rejected and the whole regression is significant. The coefficient of determination indicates that about $71 \%$ of the dependent variable variations are explained by the independent variables, indicating that the model is well fitted.

According to other results of this study, terrorism has had a positive and significant effect on capital outflow. Terrorism has also had positive proximity effects on capital outflows in other countries. The occurrence of terrorist incidents, such as the occurrence of a civil war that may lead to the phenomenon of capital flight, can lead to a large decrease in the flow of capital into the country. Terrorist incidents may impose negative external effects on neighboring countries. In other words, the internal conflicts caused by a terrorist attack in a neighboring country can reduce the inflow of capital to neighboring countries. Also, trade openness had a significant negative effect on capital outflow. Openness of the economy and freedom of the economy are fundamental requirements in the world of trade and capital transfer. Foreign investors do not operate in an economy with high barriers and tariffs. Economic freedom creates a favorable environment for investment by creating a favorable environment by removing restrictions on the production, distribution, and consumption of goods and services and greater profits for investors. These results confirm the hypothesis in the economy that greater freedom in the economy results in more foreign direct investment 
flows.

Results of this study showed that GDP had negative and significant effect on capital outflow. Increasing the GDP of countries, by strengthening infrastructure and expanding economic capacity, allows for more foreign direct investment.

\section{Conclusion and suggestions}

The purpose of this study was to investigate the effect of terrorist activities on capital flight in the Middle East countries during the period 2000-2016 using the spatial econometric panel data approach. The results of this study showed that terrorism and its spatial effects had a significant and positive impact on capital flight from the Middle East countries. Also, GDP and trade openness had negative effects on capital outflow. Countries affected by terrorist activities are suggested to increase their efforts to gather information on these incidents to prevent continued losses in the stock markets, as this would increase the confidence of foreign and local investors. In addition, policies, including improved information and law enforcement, must be developed by affected countries to eliminate or reduce the risks of terrorist attacks. Better information can bring about a significant reduction in terror-related incidents and improve country's security and peace, boosting investor confidence to strengthen stock market. Future studies can focus on measuring the damage to various sectors of the economy, such as stock markets, human capital and growth.

\section{References}

1. P. Davoodi, A. Shahmoradi. Economic Research, 3, 89-113 (2004).

2. B. Soleimani, H. Panahi, O. Jamshidi. Journal of Regional Economics and Development, 23-45 (2014)

3. S. Moshiri, S. Kianpour. Quantitative Economics Quarterly, 2, 1-30 (2012)

4. A. Abadie, G. Javier, European Economic Review, 52(1), 1-27 (2008).

5. A .Abadie , J. Gardeazabal, European Economic Review, 52, 1-27 (2007).

6. U. Efobi,; S. Asongo, Journal of International Economics, 34, 1-14 (2016).

7. J. Bellows, E. Miguel, Public Econ. 93, 1144-1157 (2009)

8. S. Bandyopadhyay, T. Sandler, J. Younas, Oxf. Econ. Pap. 66 (1), 25-50 (2014)

9. K. Sharma, World Dev. 34 (7), 1237-1253 (2006)

10. K. Gaibulloev, T.Sandler, Peace Res. 48 (3), 355-371( 2011)

11. A. Abadie, J. Gardeazabal, American Economic Review 93 (1), 113-132 (2004)

12. S. Agrawal, CMC Senior Thesis (2011)

13. U. Akpan, S. Isihak, S.A. Asongu, African Governance and Development Institute Working Paper, 14/002, Yaoundé. (2014)

14. H. Alam, M. Akram, Z. Iqbal, Journal of Research Society of Pakistan, 54, 70-77 (2017)

15. M. Alomar, T. El-Sakka, European Journal of Economics, Finance and Administrative Sciences, 28, 116-125(2011)

16. J.E. Anderson, Res. Econ. 69 (2), 180-190 (2015)

17. K.P. Arin, D. Ciferri, N. Spagnolo, Economics Letters, 101(3), 164-167 (2008)

18. S.A. Asongu, J.Nwachukwu, German Economic Review. (2018). DOI: 10.1111/geer.12126. 
19. S. Bandyopadhyay, J. Younas, Doing Business 17. AbroadPolicy Report: 19.https://www.stlouisfed.org/ /media/Files/PDFs/publications/pub_assets/pdf/re/2014 /d/terrorismpdf (Accessed: 29/04/2015).

20. S. Bandyopadhyay, T. Sandler, J. Younas, Federal Reserve Bank of St. Louis, Working Paper 2011-004A, doi: 10.2139/ssrn.1745142.

21. F. Chau, R. Deesomsak, J. Wang, Journal of International Financial Markets, Institutions and Money, 28, 1-19 (2014).

22. H. Chen, A.F. Thomas, European Journal of Political Economy, 20(2), 249-66 (2015).

23. J. De Sousa, D. Mirza, T. Verdier, European Economic Review 107, 27-56(2018).

24. K. Drakos, Review of Financial Economics 19(3), 128-135 (2010). doi:10.1016/j.rfe.2010.01.001.

25. R. Eldor, R. Melnick, European Journal of Political Economy, 20(2), 367-386 (2004)

26. J. Elhorst, Springer Heidelberg New York Dordrecht London. (2014)

27. W. Enders, A. Sachsida. Political Research Quarterly, 59 (4), 517-531 (2006)

28. Global Terrorism Database. Report 2018. https://www.start.umd.edu/gtd/.(2018)

29. C. Hsiao, Cambridge University Press, Cambridge. (2003)

30. G. Kaplanski, H. Levy, Journal of Financial Economics, 95(2) (2010)

31. A. Khachoo, M.I. Khan, Munich Personal RePEc Archive. (2012)

32. W. Koh, Journal of Technological Forecasting and Social Change, 74(2), 129-138 (2007)

33. J.B. Lutz, M.J. Lutz, Journal of Business and Economics, 5(4), 525-534 (2014). available at: http://www.academicstar.us/UploadFile/Picture/20146/201461445249331.pdf.

34. E. Neumayer, L. Spess, World Development, 33(10), 1567- 1585 (2005)

35. C.I. Obi, Review of African Political Economy, 35(117), 417-434 (2008

36. K .Peleg, J. L. Regens, J. T. Gunter, D. H. Jaffe, Disasters 35(1), 268-283(2011). doi:10.1111/j.1467-7717.2010.01203.x.

37. M.A. Shahbaz, A. Javed, D. Amina, T. Sattar, Archives of Business Research, 2(3), (2013).doi: 10.14738/abr.23.320.

38. J. Stiglitz, The Guardian, January 22, (2003)

39. J. Tavares, Journal of Monetary Economics, 51(5), 1039-1070 (2004). doi: 10.1016/j.jmoneco.2004.04.009

40. World Bank. World Development Indicators. (2018) 